\title{
Leaders
}

\section{Current thoughts on the pathogenesis of graft versus host disease}

\author{
A L Appleton, L Sviland
}

\section{Introduction}

Bone marrow transplantation is increasingly being used to treat a variety of malignant and non-malignant diseases. ${ }^{12}$ As the toxicity of the conditioning regimen diminishes and the treatment of infections improves, graft versus host disease (GvHD) emerges as the most serious complication of allogeneic grafting. Acute GvHD typically occurs in $30-60 \%$ of recipients of allogeneic marrow grafts from HLA-matched sibling donors, ${ }^{3}$ and despite the introduction of immunosuppressive agents such as cyclosporin A and FK 506, it still has a mortality of up to $50 \%{ }^{4}$ Acute GvHD is difficult to eradicate and progression to chronic GvHD is associated with increased morbidity and mortality in long term survivors.

\section{Manifestations of GvHD}

Most cases of GvHD are seen after allogeneic bone marrow grafting, as a result of the transfer of a large number of allogeneic lymphoid cells into an immunocompromised recipient.

Division of Pathology, School of Pathological Sciences, University of Newcastle Upon Tyne, Royal Victoria Infirmary

A L Appleton

(née McGrehy)

L Sviland

Correspondence to:

Dr A L Appleton,

Department of Pathology,

Royal Victoria Infirmary,

Newcastle upon Tyne,

NE1 4LP.

Accepted for publication 17 February 1993
Figure 1 Typical diffuse erythematous maculopapular skin rash of GvHD, which predominantly affects proximal areas such as the upper arms, trunk, back (as shown) and face.
GvHD is also seen, however, in immunosuppressed patients who have been transfused with non-irradiated blood products, ${ }^{56}$ and in neonates with severe immune deficiency or very low birthweight due to the transplacental transfer of maternal $\mathrm{T}$ cells. ${ }^{78}$ It has also occasionally been described in recipients of certain types of solid organ grafts, notably small bowel and liver, and in this setting is thought to be the result of cells in the lymphoid areas of the transplanted organ mediating an allogeneic response against the recipient. 910

Typically, acute GvHD presents as a skin rash (fig 1), diarrhoea and abnormal liver function tests, with or without jaundice. Immunosuppression, which may be profound, is also a manifestation of GvHD.

Histological examination of the skin in acute GvHD shows focal or diffuse vacuolar degeneration of basal epidermal cells, with scattered eosinophilic bodies (degenerate keratinocytes) and an inflammatory infiltrate in the superficial dermis (fig 2). ${ }^{11}$ The histological features of acute rectal GvHD are single cell necrosis of individual glandular crypt cells and a stromal inflammatory infiltrate (fig 3) ${ }^{12}$; similar features are seen in the duodenum and jejenum in upper gastrointestinal GvHD. ${ }^{13}$

Histological examination of the liver shows bile duct atypia, with necrosis of individual epithelial cells producing cytoplasmic vacuolation $^{14}$; there may also be a sparse peribiliary inflammatory infiltrate, focal necrosis of hepatic parenchyma, and cholestasis. ${ }^{15}$



Figure 2 Histological features of acute cutaneous GvHD, showing pronounced diffuse vacuolar degeneration of basal epidermal cells and a prominent eosinophilic body (arrowed). There is a scanty inflammatory infiltrate in the superficial dermis. 


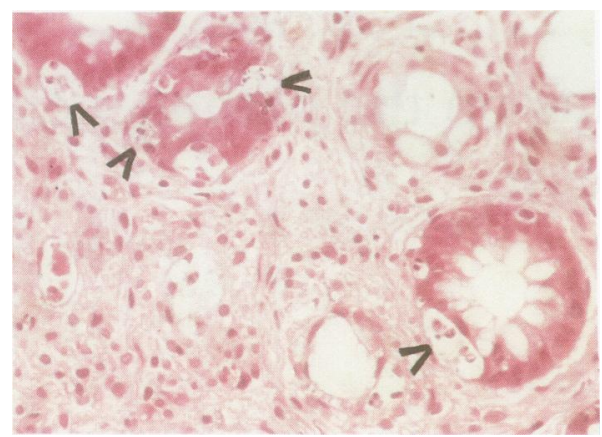

Figure 3 Histological features of acute rectal GvHD, with several glands showing single cell necrosis of individual glandular crypt cells (arrowed), and a scanty mixed cell inflammatory infiltrate within the stroma.

\section{Aetiology of epithelial cell damage}

The lesion common to GvHD in all affected organs is apoptosis of individual epithelial cells. This single cell necrosis is often, although not always, associated with a lymphocytic infiltrate. The epithelial damage associated with GvHD is in some way caused by donor effector cells reacting against recipient alloantigens, ${ }^{16}$ although the exact nature of the effector cell population in man remains a subject of controversy.

For reasons that are not fully understood, the principal target organs of $\mathrm{GvH}$ effector cells are the skin, gastrointestinal tract, hepatic biliary tree, bone marrow and lymphoid tissue. A possible reason for this apparent predilection for organs with a high cell turnover is that the continual expression of differentiation antigens by the cells of such organs triggers increased immune surveillance, ${ }^{17}$ although an alternative explanation is that the cells of these organs may harbour latent viruses which may act as a target for donor immune surveillance. ${ }^{18}$

\section{Pathogenesis of GvHD}

In man this is the subject of considerable controversy. Several theories based on experimental models and on clinical observations have been suggested. Few satisfactory animal models are available; unfortunately, GvHD behaves differently in rodents than it does in man. Primates probably offer the best animal model, but studies of GvHD in primates have proved difficult and expensive.

Although donor $\mathrm{T}$ lymphocytes are generally agreed to be the primary aggressors in establishing the graft versus host reaction, ${ }^{19-21}$ the pathogenesis of GvHD itself is far from clear. As long ago as 1971, Elkins made the distinction between the experimental graft versus host reaction (GvHR), which is the response of immunocompetent donor cells to the histocompatibility antigens of the immunocompromised recipient and which may be modified by a variety of immune and nonimmune functions, and GvHD, which is the clinical manifestation of the GvHR. ${ }^{22}$ This area is still controversial and remains poorly understood.
Cytokines or direct cell damage?

The debate continues as to whether the epithelial damage mediated by $\mathrm{GvH}$ effector cells is directly inflicted by the cells themselves or, alternatively, mediated by cytokines released from these cells. Cytokines are regulatory molecules produced in response to an antigenic stimulus which form a complex network of communication between immunocompetent cells and which have a central role in $\mathrm{T}$ cell activation.

The role of cytokines in GvHD was first postulated in 1971. Streilein's “innocent bystander" theory proposed that the primary attack by donor effector cells is on host lymphocytes; this triggers the release of cytokines and results in "second-hand" damage to the skin and gastrointestinal tract-the "innocent bystanders". ${ }^{23}$ This theory was later supported by the experimental animal work of others such as Elson and Mowat. ${ }^{24} 25$ The fact that the skin, gut, and liver have been shown to be particularly vulnerable to the effects of cytokines ${ }^{2326}$ may further explain the targeting of these organs in GvHD.

Several groups have since studied the role of individual cytokines in the pathogenesis of GvHD. The $T$ cell derived cytokine gamma interferon $(\gamma \mathrm{IFN})$, which induces class II HLA antigen expression on epithelial cells, ${ }^{27}$ has been implicated in GvHD. Aberrant expression of HLA class II antigens by keratinocytes and enterocytes is a feature of GvHD. ${ }^{28} 29$ Anti- $\gamma$ IFN monoclonal antibody preparations have been shown to prevent the characteristic enteropathy of GvHD in mice. ${ }^{26} 30$

Tumour necrosis factor alpha (TNFa), which is a macrophage derived cytokine with multistimulatory effects on $\mathrm{T}$ cells and which is an important mediator of the inflammatory process, has also been implicated in $\mathrm{GvHD} .{ }^{31-33}$

In their study of a skin explant model of GvHD $^{34}$ Dickinson et al showed that TNFa causes histological changes in vitro similar to those seen in GvHD. ${ }^{35}$ They also showed evidence of synergy between TNF $a$ and $\gamma \mathrm{IFN}$. These have already been shown to act together to produce local responses to antigenic stimuli. ${ }^{36}$

The role of other cytokines, such as interleukin-2 (IL-2), in GvHD is less clearly defined. Several workers have found a correlation in bone marrow transplant recipients between $\mathrm{GvHD}$ and raised concentrations of the soluble form of the IL-2 receptor complex (s-IL-2R), which is shed from activated $\mathrm{T}$ cells into the serum..$^{37}$ There is some evidence that monoclonal antibodies directed against $\mathrm{IL}-2 \mathrm{R}$ are effective at preventing murine GvHD, ${ }^{39}$ although there is less convincing evidence for their clinical efficacy. ${ }^{4041}$

There is also evidence, however, that the cellular damage characteristic of GvHD may be caused by direct cell damage rather than indirectly through soluble mediators. Electron microscopic studies have shown evidence of intimate contact between effector cells and target epithelial cells in GvHR. ${ }^{42-44}$ These studies show that cytotoxic $T$ cells may inflict tissue damage by direct cell to cell con- 
tact. Small numbers of T cells may be able to produce clinically important damage in GvHD, because cytotoxic $T$ cells may move from one target cell to another, destroying multiple epithelial cells.

There is also evidence that some direct cell killing may occur as a result of the activity of natural killer cells ${ }^{45}$ which are non-HIA restricted. The histology of GvHD certainly supports this theory; acute GvHD affects immature cells, in both the basal layer of the epidermis in the skin and in the intestinal crypts. Studies of the anti-tumour activity of natural killer cells have shown that they exhibit more activity against undifferentiated tumour cells expressing "fetal-like" antigens than against their more differentiated counterparts. ${ }^{46}$ Indeed, some workers believe that the cell is the effector cell in murine GvHD. ${ }^{47} 48$

\section{Effector cell population}

As previously indicated, the exact nature of the effector cell population in human GvHD is unclear. Several workers have attempted to determine the pathogenic cell type in GvHD.

Many studies have shown that the predominant $T$ cells in the lesional tissue of GvHD are CD8+ $\mathrm{T}$ cytotoxic (suppressor) cells..$^{49} 50$ These data have been extrapolated to implicate $\mathrm{CD} 8+$ cells in the pathogenesis of GvHD and have formed the basis for suggestion that the CD8+ $T$ cell population is the effector cell population in GvHD. ${ }^{51} 52$

Tissue lymphoid repopulation, however, may merely reflect lymphoid reconstitution in the peripheral blood. Many workers have shown that marrow grafting is followed by a reversal in the peripheral CD4+:CD8+ ratio, which is normally $2: 1 . .^{54}$ This reversal in the normal CD4+:CD8+ ratio occurs regardless of the presence or absence of GvHD. ${ }^{55}$ The increase in the number of CD8+ cells in the period after transplantation seems to correlate merely with increasing time after transplantation and not with the development of GvHD.

Thus the predominance of CD8+ cells in tissues affected by GvHD may merely reflect the predominance of CD8+ cells in the peripheral blood, and not an active infiltration of $\mathrm{CD} 8+$ cells into the lesional tissue, and thus may have little bearing on the pathogenesis of GvHD.

Furthermore, several recent studies, particularly in animals, have highlighted the role of the CD4+ $T$ cell in GVHD. ${ }^{56} 57$ Evidence from murine models ${ }^{58}$ and from in vitro studies of alloantigen induced cytolytic $T$ cell generation ${ }^{59}$ have indicated that both $\mathrm{CD} 4+$ and CD8+ cells are required to induce GvHD. Antihost CD4+ cells may induce GvHD by the release of cytokines, or by triggering a delayed type ( $T$ cell mediated) hypersensitivity reaction. ${ }^{6061}$

The issue of a discrete effector cell population mediating the pathogenesis of GvHD is thus unclear. Both $T$ cell subsets seem to play an important part in the mechanism of the GvHD effector pathway. It is clear that complex cellular and humoral interactions are involved.

\section{Role of environmental factors}

Although initial studies suggested that GvHD occurs only in the context of histocompatibility antigen disparity between donor-recipient pairs, ${ }^{62}$ more recent evidence has shown that GvHD can occur in the absence of HLA disparity. Histologically confirmed GvHD has been described in recipients of syngeneic and even autologous marrow. ${ }^{6364}$ Some of these patients had peritransplant viral infections, suggesting that reactivity to environmental antigens may have a role in the pathogenesis of GvHD. ${ }^{6566}$ Moreover, GvHD is clinically variable and unpredictable, ${ }^{67}{ }^{68}$ suggesting that non-MHC antigens may be involved in its exacerbation or initiation.

Over the past decade an increasing number of studies have reported an association between certain viruses and the development of GvHD in recipients of marrow grafts from HLA-matched sibling donors. ${ }^{69-72}$ The frequent clinical association of cytomegalovirus (CMV) infection with GvHD has focused particular attention on the herpes viruses, although little is known about the possible pathogenic interaction of these two processes.

Studies in animal models have shown that simultaneous infection with murine CMV and GvHR to MHC antigens seems to act synergistically to induce GvHD. ${ }^{73-75}$ Murine CMV infection alters the immune response to allogeneic and hapten-modified syngeneic histocompatibility antigens, suggesting that CMV infection can enhance the allogeneic response and result in GvHD.

Herpes viruses may augment the severity of GvHD by modulating the normal immune response of the host or by modifying the expression of histocompatibility antigens by host cells, thus altering their surface antigenicity and acting as a target for donor immune surveillance. ${ }^{76}$

Attempts to link herpes virus infection and GvHD in a causal relationship have mainly been based on seroepidemiological studies. As determined by donor and recipient seropositivity and, more recently, by the antiviral cellular immune response of the donor, both CMV and herpes simplex virus have been linked to an increased incidence of severe minor antigen induced GvHD. ${ }^{77} 78$

In a large multicentre study, seropositivity to CMV before bone marrow transplant was identified as the major risk factor for the development of moderate to severe GvHD in multivariate analysis. ${ }^{79}$ Positive donor and recipient seropositivity to $\mathrm{CMV}$ was also a major risk factor for the development of chronic GvHD. However, no studies have attempted prospectively to analyse organs affected by GvHD for herpes virus infection.

\section{Future directions}

GvHD is a fascinating disease which presents a useful model for a variety of immunological diseases and which provides insights into the mechanisms of immunocompetence and its establishment.

Further research aimed at improving our 
understanding of transplantation immunology in general, and the pathogenesis of GvHD in particular, is required. Bone marrow transplantation is emerging as an important treatment modality for an increasing range of life threatening diseases, but its wider application is limited by failure to resolve the most serious complication of allogeneic grafting. A greater understanding of the pathogenesis of GvHD would enable allogeneic transplantation to be offered to patients without HLAmatched sibling donors and would make safer the transplantation of marrow from mismatched and matched unrelated donors.

It may not be possible to eradicate GvHD, and, indeed, the loss of the beneficial graft versus leukaemia (GVL) effect associated with GvHD may not be desirable in some patients. Graft manipulation which results in eradication of GvHD is also associated with reduced marrow engraftment and increased rejection (host versus graft reaction). ${ }^{8081}$ Improvements in the prevention and treatment of GvHD, however, are necessary.

Current investigations into the efficacy of immunomodulators such as monoclonal antibodies directed against individual cytokines and their cellular receptors are producing some promising results. ${ }^{82-84}$ Similarly, manipulation of graft effector cell activity through graft $T$ cell depletion and the use of antithymocyte globulin (ATG) have proved of benefit, ${ }^{8586}$ and as evidence emerges that the cells mediating GVL are at least partially distinguishable from those causing $\mathrm{GvHD},{ }^{87}$ selective $T$ cell depletion of allogeneic grafts is likely to become an increasingly successful technique.

A clearer understanding of the association between herpes viruses and GvHD also has implications for the management of bone marrow transplant recipients. Definitive evidence that herpes virus infection exacerbates GvHD would justify active prophylaxis with acyclovir, or passive prophylaxis with antiCMV hyperimmune globulin, for all recipients, and would indicate clearly the need for increased viral surveillance, with effective and early treatment of viral infective episodes, in seropositive patients.

We thank Dr Archie J Malcolm at the University of Newcastle Upon Tyne, for his help and advice.

We also thank the North of England Cancer Research Campaign, who are funding Dr Appleton for a related doctorate study.

1 Thomas, ED. Marrow transplantation for malignant disease. f Clin Oncol 1989;9:517-30.

2 Bortin MM, Rim AA. Increasing utilization of bone marrow transplantation II: Results of the 1985-1987 survey. Transplantation 1989;48:453-8.

3 Wagner Jr, JE, Vogelsang, GB, Beschorner WE. Pathogenesis and pathology of graft-vs-host disease. $\mathrm{Am}$ Pathogenesis and pathology of graft-vs-ho

4 Bortin MM, Rimm AA. Treatment of 144 patients with severe aplastic anaemia using immunosuppression and allogeneic marrow transplantation. A report from the International Bone Marrow Transplantation Registry. Transplant Proc 1981;13:227-9.

5 Decoste SD, Boudreaux C, Dover JS. Transfusion-associated graft-vs-host disease in patients with malignancies. Arch Dermatol 1990;26:1324-9.

6 Burns LJ, Westburg MW, Burns CP, et al. Acute graftversus-host disease resulting from normal donor blood transfusions. Acta Hematol 1984;71:270-6.
7 Funkhouser AW, Vogelsang G, Zehnbauer B, et al. Graftversus-host disease after blood transfusions in a premature infant. Pediatrics 1991;87:247-9.

8 Flidel O, Barak Y, Lifschitz-Mercer B, Frumkin A, Mogilner BM. Graft-versus-host disease in extremely Mogilner BM. Graft-versus-host disease in extreme

9 Jamieson NV, Joysey V, Friend PJ, et al. Graft-versus-host disease in solid-organ transplantation. Transplant Int 1991;4:67-71.

10 Collins RH, Cooper B, Nikaein AA, Klintmalm G, Fay $\mathrm{JW}$. Graft-versus-host disease in a liver transplant recipient. Ann Int Med 1992;116:391-2.

11 Lerner KG, Kao GF, Storb R, Buckner CD, Clift RA, Thomas ED. Histopathology of graft-versus-host reaction (GvHR) in human recipients from marrow from HLA-matched sibling donors. Transplant Proc 1974;6: 367-71.

12 Sviland L, Pearson ADJ, Eastham, EJ, and the Newcastle Upon Tyne Bone Marrow Transplant Group. Upon Tyne Bone Marrow Transplant Group. Histological features of skin and rectal biopsy specimens after autologous and allogeneic bone
tation. $₹$ Clin Pathol 1988;41:148-54.

13 Appleton AL, Sviland L, Pearson ADJ, Green MA, Eastham EJ, Malcolm AJ. The need for endoscopic biopsy in the diagnosis of upper gastrointestinal graftversus-host disease. $\mathcal{F}$ Pediatr Gastro Nutrition 1993;16. 183-5.

14 Snover DC, Weisdorf SA, Ramsay NK, McGlave P, Kersey JH. Hepatic graft-versus-host disease: A study of the predictive value of liver biopsy in diagnosis. the predictive value of

15 Nonomura A, Kono N, Mizukzmi Y, Nakanuma Y, Matsubara F. Histological changes in the liver in experimental graft-versus-host disease across minor histocommental graft-versus-host disease across minor histocompatibility barriers VI. A light and electron microscopic
study of the peri-portal changes. Liver 1991;11:278-86.

16 Elkins WL. An immunological approach to the graft-vshost reaction and secondary disease. In: Gale RF, Fox FC, ed. Biology of bone marrow transplantation. New York: Academic Press, 1980:195.

17 Sale GE, Shulman HM, Gallucci BB, Thomas ED. Young rete ridge keratinocytes are preferred targets in cutaneous graft-versus-host disease. Am F Pathol 1985; 118:276-87.

18 McCarthy AL, Peiris JSM, Taylor CE, et al. Increase in severity of graft-versus-host disease by cytomegalovirus. severity of graft-versus-host
f Clin Pathol 1992;45:542-4.

19 Van Els CACM, Bakker A, Zwinderman AH, et al. Effector mechanisms in graft-versus-host disease in response to minor histocompatibility antigens I Absence of correlation with cytotoxic effector cells. Transplantation 1990;50:62-6.

20 Van Els CACM, Bakker A, Zwinderman AH, et al. Effector mechanisms in graft-versus-host disease in response to minor histocompatibility antigens II. Evidence of a possible involvement of proliferative cells. Transplantation 1990;50:67-71.

21 Van Els CACM, Zantvoort E, Jacobs N, et al. Graft-versus-host disease associated $\mathrm{T}$ helper cell responses specific for minor histocompatibility antigens are mainly cific for minor histocompatibility antigens are mainly restricted by HLA-DR

22 Elkins WL. Cellular immunology and the pathogenesis of graft-versus-host reactions. Prog Allergy 1971;15: 178-87.

23 Streilein JW. A common pathogenesis for the lesions of graft-versus-host disease. Transplant Proc 1971;3: 418-21.

24 Elson CO, Reilly RW, Rosenburg IH. Small intestinal injury in the graft-versus-host reaction: An innocent bystander phenomenon. Gastroenterology 1977;72:886-9.

25 Mowat AMcI. Evidence that Ia + bone-marrow-derived cells are the stimulus for the intestinal phase of the murine graft-versus-host reaction. Transplantation 1986; 42:141-4.

26 Mowat AMcI. Antibodies to IFN-gamma prevent immunologically mediated intestinal damage in murine graft-versus-host disease. Immunology 1989;68:18-23.

27 Guy-Grand D, Vassalli P. Gut injury in mouse graft-versus-host reaction. Study of its occurrence and mechanisms. F Clin Invest 1986;77:1584-95

28 Sviland L, Pearson ADJ, Eastham EJ, et al. Class II antigen expression by keratinocytes and enterocytesAn early feature of graft-versus-host disease. Transplantation 1988;46:402-6.

29 Sviland L, Pearson ADJ, Eastham EJ, Green MA Malcolm AJ. Expression of MHC class I and class II antigen expression by keratinocytes and enterocytes in acute graft-versus-host disease. Bone Marrow Transplant acute graft-versus

30 Landolfo S, Cofano F, Giovarelli M, Prat M, Cavallo G, Forni $\mathrm{G}$. Inhibition of interferon-gamma may suppress allograft reactivity by $T$ lym
vivo. Science $1985 ; 229: 176-9$.

31 Shalaby MR, Fendly B, Sheehan K, Schreiber RD, Ammann, AJ. Prevention of the graft-versus-host reaction in newborn mice by antibodies to tumor necrosis factor alpha. Transplantation 1989;47:1057-61

32 Symington FW, Pepe MS, Chen AB, Deliganis A. Serum tumour necrosis alpha associated with acute graft-versus-host disease in humans. Transplantation 1990;50: 518-21.

33 Piguet PF, Grau GE, Allet B, Vassalli P. Tumour necrosis factor/cachectin is an effector of skin and gut lesions of the acute phase of graft-versus-host disease. $\mathcal{F}$ Exp Med 
1987;166:1280-9.

34 Dickinson AM, Sviland L, Carey P, et al. Skin explant culture as a model for cutaneous graft-versus-host disease in humans. Bone Marrow Transplant 1988;3:323-9.

35 Dickinson AM, Sviland L, Dunn J, Carey P, Proctor SJ Demonstration of direct involvement of cytokines in graft-versus-host reactions using an in vitro human skin explant model. Bone Marrow Transplant 1991;7:209-16.

36 Wong G, Goeddel DV. Tumour necrosis factors alpha and beta inhibit virus replication and synergise with interferons. Nature 1986;323:819.

37 Alessandrine EP, Bernascoui P, Colombo A. Levels of soluble low affinity II 2 receptors (s-II2R) and TNF in the serum after bone marrow transplantation. Bone Marrow Transplant 1991;7(suppl 2):51.

38 Siegert W, Josimovic-Alasevic O, Schwerdffeger R, et al. Soluble interleukin 2 receptors in patients after bone marrow transplantation. Bone Marrow Transplant 1990;6:97-101.

39 Blaise D, Maranchini D, Mawas C, et al. Prevention of acute graft-versus-host disease by monoclonal antibody to interleukin-2 receptor. Lancet 1989; ;:1333-4.

40 Belanger C, Esperou-Bourdeau H, Raffoux C, Gluckman E. For the GEGMO Group. Unrelated bone marrow transplantation. Use of $I 12$ receptor monoclonal antibody (II 2-R-Ab) in the prophylaxis of GVHD. Bone Marrow Transplant 1991;7(suppl 2):122.

41 Tiley C, Powles R, Teo, CP, Treleaven J, Findlay M, Hewetson M. Treatment of acute graft-versus-host disease with a monoclonal antibody to the IL-2 receptor. Bone Marrow Transplant 1991; 7(suppl 2): 151 .

42 Woodruff JM, Butcher WI, Hellerstein, LJ. Early secondary disease in the rhesus monkey II: electron microscopy of changes in the mucous membranes and external epithelium as demonstrated in the tongue and lip. Lab Invest 1972;27:85-98.

43 Gallucci BB, Sale GE, McDonald GB, et al. The fine structure of human rectal epithelium in acute graft-vsstructure of human rectal epithelium in acute
host disease. Am I Surg Pathol 1982;6:293-305.

44 Sale GE, Gallucci B, Schubert MM, et al. Direct ultrastructural evidence of target-directed polarization by cytotoxic lymphocytes in lesions of graft-vs-host disease. Arch Pathol Lab Med 1987;111:333-6.

45 Dokhelar MC, Wiels J, Lipinski M, et al. Natural killer cell activity in human bone marrow recipients: early appearance of peripheral NK cell activity in GVHD. Transplantation 1981;31:61-5.

46 Roder JC, Pross HF. The biology of the human natural killer cell. 7 Clin Immunol 1982;2:249-63.

47 Guillen FJ, Ferrara J, Hancock WW, et al. Acute cutaneous graft-vs-host disease to minor histocompatibility antigens in a murine model. Evidence that large granuantigens in a murine model. Evidence that large granular lymphocytes are effector cells
response. Lab Invest 1986;55:35-42

48 Ghayur T, Seemayer TA, Konshavn PAL, et al. Graft-vshost reactions in beige mice: an investigation of the role of host and donor natural killer cells in the pathogenesis of GVH disease. Transplantation 1987;44:261-7.

49 Guyotat D, Mauduit G, Chouvet B, et al. A sequential study of histological and immunological changes in the skin after bone marrow transplantation. Transplantation 1986;41:340-2.

50 Dilly SA Sloane JP. Changes in rectal leucocytes after allogeneic bone marrow transplantation. Clin Exp allogeneic bone marro

51 Korngold R, Sprent J. Surface markers of $T$ cells causing lethal graft-versus-host disease to class I vs class II $\mathrm{H}-2$ differences. $尹$ Immunol 1985;135:3004-10.

52 Sprent J, Schaefer M, Lo D, Korngold R. Properties of purified $T$ cell subsets II. In vivo response to class II $\mathrm{H}$ 2 differences. $₹$ Exp Med 1986;163:998-1011.

53 Witherspoon RP, Lum JG, Storb R. Immunological reconstitution after human marrow grafting. Semin Hematol 1984;21:2-10.

54 Atkinson K, Hansen JA, Storb R, et al. T-cell subpopulations identified by human monoclonal antibodies after human marrow transplantation I. Helper-inducer and cytotoxic-suppressor subsets. Blood 1982;59:1292-7.

55 Sviland L, Pearson ADJ, Green MA, et al. Immunopathology of early graft-versus-host disease-A prospec-
tive study of skin, rectum and peripheral blood in tive study of skin, rectum and peripheral brood in recipients. Transplantation 1991;52:1029-36.

56 Sakamoto H, Michelson J, Jones WK, et al. Lymphocytes with a CD4 + CD8-CD3-phenotype are effectors of experimental cutaneous oraft-versus-host disease. Proc Natl Acad Sci USA 1991;88:10890-4.

57 Truitt RL, Atasoylu AA. Contribution of CD4+ and $\mathrm{CD} 8+\mathrm{T}$ cells to graft-versus-host disease and graftversus-leukaemia reactivity after transplantation of
MHC-compatible bone marrow. Bone Marrow Transplant 1991;8:51-8.

58 Rolink AG, Gleichman E. Allosuppressor- and allohelper$T$ cells in acute and chronic graft-versus-host disease. TII. Different lyt subsets induce different pathological iII. Different lyt subsets induce differe

59 Prince HE, John JK. Flow cytometric analysis of lymphocyte activation in the mixed lymphocyte response. Immunol Invest 1988; 17:309-19.

60 Van Els C, Bakker A, Van Rood J, Goulmy E. Differen biology and pathology of minor alloantigen-specific cytotoxic and proliferative T cells. Transplant Proc 1991, 23:429-30.

61 Prince HE. The significance of $T$ lymphocytes in trans- fusion medicine. Transfusion Med Rev 1992;6:32-43.

62 Billingham RE. The biology of graft-versus-host reactions. Harvey Lectures 1966;67:21-78.

63 Gluckman E, Devergie A, Sohier, J, Saurat JH. Graftversus-host disease in recipients of syngeneic bone marrow. Lancet 1980;i:253-4.

64 Thein SL, Goldman JM, Galton DG. Acute "graft-versushost disease" after autografting for chronic granulocytic leukaemia in transplantation. Ann Intern Med 1981; 94:210-11.

65 Ringden O, Lonnqvist B, Paulin T, et al. Factors associated with chronic graft-versus-host disease and cytomegalovirus infection in bone marrow transplant cytomegalovirus infection in bone marr

66 Miller W, Flynn P, McCullough J, et al. Cytomegalovirus infection after bone marrow transplantation: an association with acute graft-vs-host disease. Blood 1986;67: 1162-7.

67 Bross DS, Tutschka PJ, Farmer ER, et al. Predictive factors for acute graft-versus-host disease in patients transplanted with HLA-identical bone marrow. Blood 1984; 63:1265-70.

68 Gale RP, Bortin MM, Van Bekkum DW, et al. Risk factors for acute graft-versus-host disease. $\mathrm{Br} \mathcal{F}$ Haematol 1987;67:398-406.

69 Bostrom L, Ringden O, Sindberg B, Linde A, Tollemer J, Nilson B. Pretransplant herpes virus serology and graftversus-host disease. Transplantation 1988;46:548-52.

70 Gratama JW, Zwaan FE, Stijnen T, et al. Herpes virus immunity and acute graft-versus-host disease. Lancet 1987;i:471-3.

71 Lonnqvist B, Ringden O, Wahren B, Gahrton G, Lundgren $G$. Cytomegalovirus infection associated with and preceding chronic graft-versus-host disease. Transplantation 1984;38:465-8.

72 Asano Y, Yoshikawa T, Suga S, et al. Reactivation of herpesvirus type 6 in children receiving bone marrow transplants for leukaemia. N Engl f Med 1991:324: 634-5.

73 Via CS, Shanley JD, Weatherly BR, Lang P, Shearer GM Altered threshold for the induction of graft-versus-host immunodeficiency following murine cytomegalovirus immunodeficiency following murine cytomegalovirus infection. Host and

74 Grundy JE, Reid MF. The effect of primary and secondary infection with cytomegalovirus on the host response to alloantigens. Transplant Proc 1985;17: 592-4.

75 Cray C, Levy RB. The ability of murine cytomegalovirus and class I major histocompatibility complex-disparate parental cells to induce alterations characteristic of severe graft-versus-host disease. Transplantation severe graft-vers

76 McCarthy AL, Sviland L. Pathogenesis of GVHD: the role of herpes viruses. Bone Marrow Transplant 1993; role of herpes

77 Bostrom L, Ringden O, Forsgren $M$. Strong donor mononuclear cell reactivity for herpes simplex virus (HSV) antigen in HSV immune donors combined with recipient seropositivity for HSV is associated with acute graft-versu.

78 Bostrom L, Ringden O, Gratama JW, et al for the Leukaemia Working Party Of The European Group For Bone Marrow Transplantation. A role of herpes virus serology for the development of acute graft-versus-host serology for the development of acute graft-ve.
disease. Bone Marrow Transplant 1990;5:321-6.

79 Bostrom L, Ringden O, Gratama JW, Jacobsen N, Zwaan F, Nilsson B, for the Leukaemia Working Party of the F, Nilsson B, for the Leukaemia Working Party of the European Group For Bone Marrow Transplantation. The impact of pre-transplant herpesvirus serology on Proc 1990;22:206-7.

80 Wagner JE, Zahurak M, Piantadosi S, et al. Bone marrow transplantation of chronic myelogenous leukaemia in chronic phase: evaluation of risks and benefits. $\mathcal{F}$ Clin Oncol 1992;10:779-89.

81 Champlin RE. T-cell depletion for bone marrow transplantation: effects on graft rejection, graft-versus-host disease, graft-versus-leukaemia and survival. Cancer Treat Res 1990;50:99-111.

82 Herve $P$, Racadot $E$, Wiidenes $J$, et al. Monoclonal antiTNF alpha antibody in the treatment of acute GVHD refractory both to corticosteroids and anti-IL-2R antibody. Bone Marrow Transplant 1991;7:149.

83 Blaise D, Guyotat D, Reiffers J, et al. Prospective randomized study of GVHD prevention using an anti-IL-2 receptor (CD25) moAb after allogeneic bone marrow transplantation (BMT). Bone Marrow Transplant 1991; 7(suppl 2): 150

84 Anasetti C, Martin PJ, Storb P, et al. Prophylaxis of graftversus-host disease by administration of the murine anti-II-2 receptor antibody 2A3. Bone Marrow Transplant 1991;7:375-81.

85 Wiesneth $M$, Hertenstein B, Bunjes $D$, et al. T-cell depletion versus methotrexate as GVHD prophylaxis in allogeneic bone marrow transplantation for leukaemia. Eur $¥$ Haematol 1988;41:243-9.

86 Storb R, Gluckman R, Thomas ED, et al. Treatment of established human graft-versus-host disease by anti-thymocyte globulin. Blood 1974;44:57-75.

87 Horowitz MM, Gale RP, Sondel PM, et al. Graft-versusleukaemia reactions after bone marrow transplantation. Blood 1990;75:555-62. 